\title{
Tissue Typing, Antilymphocyte Globulin, and Prophylactic Graft Irradiation in Cadaver Kidney Transplantation
}

\author{
J. A. MYBURGH, ${ }^{*}$ cH.M., F.R.C.S. ; B. GOLDBERG, † M.D., M.R.C.P. ; A. M. MEYERS, $\ddagger$ M.B., F.C.P.(S.A.) \\ P. J. P. VAN BLERK, $\oint$ M.B., DIP.SURG. ; L. GECELTER,\| M.B., F.R.C.S. ; C. J. MIENY, I CH.M., F.R.C.S., F.C.S.(S.A.) \\ S. BROWDE, ${ }^{* *}$ M.B., B.CH., M.MED.(RAD.) ; M. SHAPIRO, †† D.SC., M.B., CH.B. ; A. ZOUTENDYK, $\ddagger$ M.D. \\ C. G. ANDERSON, $\ddagger$ PH.D.
}

\begin{abstract}
Summary: In a series of 27 recipients of cadaver kidney grafts, 26 were at the time of writing alive, 3 to 25 months after transplantation, and 25 patients were alive with functioning first grafts. The one-year patient survival in 18 patients was $94 \%$ and the one-year graft survival was $89 \%$. There was no beneficial correlation between tissue matching and the frequency of major early rejection episodes or graft function 12 or more months after transplantation. Antilymphocyte globulin administration was associated with a lower incidence of early rejection episodes, but this was not statistically significant. A combination of prophylactic graft irradiation and antilymphocyte globulin administration for at least the first two weeks was associated with a significantly reduced frequency of major early rejection episodes and appreciably better graft function at 12 months. This effect could not be ascribed to better tissue matching.
\end{abstract}

\section{Introduction}

There is no complete certainty about the value of histocompatibility matching, the use of antilymphocyte globulin, or the use of prophylactic graft irradiation in human cadaver kidney transplantation. This report analyses the effects of these three variables against a background of standardized basic immunosuppressive therapy in a series of 27 cadaver kidney transplants performed in a two-year period.

\section{Patients and Methods}

Patients.-Previous experience with hyperacute rejection in three patients has been published (Myburgh et al., 1969). Twenty-eight patients received cadaver kidney transplants for the first time at the Johannesburg General Hospital in the two-year period ending February 1970. Hyperacute rejection occurred in one of these patients despite a negative lymphocytotoxicity reaction between recipient serum and donor lymphocytes. The remaining 27 are analysed in this report.

Basic Immunosuppression.-All patients received azathioprine and prednisolone from the time of transplantation. Azathioprine $4 \mathrm{mg} . / \mathrm{kg}$. body weight was given immediately a donor became available. Prednisolone $200 \mathrm{mg}$. was administered intravenously five minutes before release of vascular clamps. Postoperatively the dose of azathioprine was varied according to the level of renal function and the white cell count. In the presence of acute tubular necrosis the dose

* Professor of Surgery.

+ Principal Physician.

† Principal Physian.

Chief Urologist.

Part-time Urologist.

Senior Surgeon.

* Radiotherapist.

itwatersrand University Medical School and Johannesburg General Hospital, Johannesburg, South Africa

t† Director, South African Blood Transfusion Service.

\# South African Institute for Medical Research. was reduced to $1-1.5 \mathrm{mg} . / \mathrm{kg} . /$ day and was increased progressively when creatinine clearance attained $20 \mathrm{ml} . / \mathrm{min}$. A maintenance dose of $3 \mathrm{mg} . / \mathrm{kg}$./day was aimed for provided the white cell count remained above $5,000 / \mathrm{cu} . \mathrm{mm}$. All patients received $200 \mathrm{mg}$. of prednisolone on the first postoperative day. This dose was reduced by $20 \mathrm{mg}$./day until $100 \mathrm{mg}$. was reached and then by $10 \mathrm{mg}$./day to a level of $60 \mathrm{mg}$./day. Further decrements of $5 \mathrm{mg}$./day every three to four weeks reduced the dose to a minimum level of $10 \mathrm{mg}$./day.

Histocompatibility Matching.-Prospective tissue typing was carried out in all patients by two independent laboratories. One of the laboratories (A.Z., South African Institute for Medical Research) uses leuco-agglutinating sera recognizing the following "antigens" (van Rood's nomenclature): 4a, 4b, 5a, 5b, 6a, 6b, 7a, 7b, 7c, 7d, 8a, and 9a. The other laboratory (M.S., South African Blood Transfusion Service) uses a panel of over 60 lymphocytotoxic sera recognizing the following specificities : HL-A1, HL-A2, HL-A3, HLA5, HL-A7, HL-A8, HL-A9, HL-A10, HL-A11, HL-A12, Lc17, Lc20, and Te10. Incompatibility was considered present if the donor possessed an antigen lacking in the recipient. An A match refers to identity between donor and recipient; a B match contains no major incompatibilities as defined above; a $C$ match refers to 1 incompatibility; and a D match refers to 2 or more major incompatibilities. Recipients with the best matches were selected for transplantation, but for logistic reasons all suitable kidneys were used irrespective of the quality of the match, provided no preformed lymphocytotoxic antibodies were detected on direct crossmatch. On occasions urgent clinical considerations-for example, progressive neuropathy-overrode matching.

Antilymphocyte Globulin.-Equine antilymphocyte globulin (thymocytes as antigen) was prepared by $20 \%(0.4)$ ammonium sulphate precipitation and diethylaminoethanol Sephadex column chromatography of the crude serum. The final product had an immunoglobulin content of $20 \mathrm{mg} . / \mathrm{ml}$. The lymphocytotoxicity titre was $1: 2,000$, leucoagglutinin titre $1: 8 ; 000$, and rosette inhibition titre 1:500, and the lymphocytes incubated with the antilymphocyte globulin showed positive immune adherence with human red cells. Haemagglutinin and haemolysin titres were reduced to zero by absorption with human red blood cells. The antilymphocyte globulin was usually administered in daily intramuscular doses of $2 \mathrm{mg} . / \mathrm{kg}$. A few patients received $4 \mathrm{mg}$. $/ \mathrm{kg}$./day intravenously.

Graft Irradiation. - This was administered from a cobalt-60 source. Individual doses at the level of the graft were 150 rads.

Rejection Episodes.-Minor fluctuations in graft function were seen in most patients, usually associated with reductions in steroid dosage. These responded to small increments in steroid dosage, usually to $5 \mathrm{mg}$. above the dose at which graft function previously had been stable. Episodes characterized by unequivocal and progressive deterioration of graft function and requiring drastic intensification of immunosuppressive 
therapy have been designated "major rejection episodes" for the purposes of the ensuing analysis.

Graft Function.-In the analysis the serum creatinine level has been chosen as the single most useful index of renal function. Normal function refers to serum creatinine levels of under $1.4 \mathrm{mg} . / 100 \mathrm{ml}$. in females and under $1.6 \mathrm{mg} . / 100 \mathrm{ml}$. in males, the upper levels of normal in our laboratories being 1.3 and $1.5 \mathrm{mg} . / 100 \mathrm{ml}$. respectively.

\section{Results}

Patient and Graft Survival.-At the time of writing 26 (96\%) of the 27 patients were alive, three months to two years after transplantation. One patient died at home of massive pulmonary embolism five months after transplantation. Graft function was normal at the time of death. Twenty-five $(93 \%)$ of the patients were alive with functioning first grafts. Nephrectomy was performed in one patient six months after transplantation. Multiple incompletely reversed rejection episodes led to cessation of immunosuppressive therapy. All patients were at least three months post-transplantation, and in 23 patients at least six months had elapsed since transplantation. Eighteen patients have been followed for at least one year since transplantation. Seventeen $(94 \%)$ of these were alive and $16(89 \%)$ were alive with functioning first grafts. All five patients transplanted 18 months to two years previously were alive with functioning first grafts. Two patients have passed their second anniversary since transplantation.

Tissue Matching.-The effects of tissue matching on the frequency of significant early rejection episodes and graft function 12 months or more after transplantation are given in Table I. Eleven patients had A or B matches and 14 had C or $\mathrm{D}$ matches. (Matching was indeterminate in two patients because of paucity of specific antisera.) A somewhat larger fraction of patients with A-B matches (0.56) experienced significant early rejection episodes than patients with $C-D$ matches (0.36). This difference is not statistically significant $(P>0.5)$. Similarly, the fraction with normal serum creatinine levels 12 months or more after transplantation is twice as large in the poorly-matched group $(0.45)$ as in the wellmatched group $(0 \cdot 20)$. This difference is also not statistically significant $(\mathrm{P}=0.3)$.

Antilymphocyte Globulin.-Antilymphocyte globulin and tissue matching are analysed in Table II. Eleven patients received no prophylactic antilymphocyte globulin administration, a further 11 received antilymphocyte globulin for at least two weeks after transplantation, and five received it for less than two weeks, administration being curtailed on account of severe local reactions. Tissue matching was almost identical in the first and last groups, and four of the five patients in the middle group had C-D matches (one match

TABLE I.-Effects of Tissue Matching on Frequency of Major Early Rejection Episodes and Late Graft Function

\begin{tabular}{|c|c|c|c|}
\hline $\begin{array}{c}\text { No. of } \\
\text { Patients }\end{array}$ & $\begin{array}{l}\text { Tissue } \\
\text { Match }\end{array}$ & $\begin{array}{l}\text { Patients with Major Early } \\
\text { Rejection Episodes }\end{array}$ & $\begin{array}{l}\text { Patients with Normal Serum } \\
\text { Creatinine } 12+\text { Months }\end{array}$ \\
\hline $\begin{array}{l}11 \\
14 \\
\end{array}$ & $\begin{array}{l}\mathbf{A}-\mathbf{B} \\
\mathbf{C}-\mathbf{D}\end{array}$ & $\begin{array}{l}\text { (Fraction) } \\
6(0.56) \\
5(0.36) \\
\end{array}$ & $\begin{array}{l}\text { (Fraction) } \\
1 / 5(0.20) \\
5 / 11(0.45)\end{array}$ \\
\hline & & $P>0.5$ & $P=0.3$ \\
\hline
\end{tabular}

TABLB II.-Effects of Antilymphocyte Globulin and Tissue Matching on Major Early Rejection Episodes and Late Graft Function

\begin{tabular}{|c|c|c|c|c|c|}
\hline \multirow{2}{*}{$\begin{array}{l}\text { No. of } \\
\text { Patients }\end{array}$} & \multirow{2}{*}{$\begin{array}{c}\text { Anti- } \\
\text { lymphocyte } \\
\text { Globulin }\end{array}$} & \multicolumn{2}{|c|}{$\begin{array}{l}\text { Tissue } \\
\text { Match }\end{array}$} & \multirow{2}{*}{$\begin{array}{l}\text { Patients with Major } \\
\text { Early Rejection } \\
\text { Episodes (Fraction) }\end{array}$} & \multirow{2}{*}{$\begin{array}{l}\text { Patients with Norma } \\
\text { Serum Creatinine } \\
12+\text { Months } \\
\text { (Fraction) }\end{array}$} \\
\hline & & A-B & C-D & & \\
\hline $\begin{array}{l}11 \\
5 \\
11\end{array}$ & $\begin{array}{c}0 \\
<2 \text { weeks } \\
>2 \text { weeks }\end{array}$ & $\begin{array}{l}6 \\
0 \\
5\end{array}$ & $\begin{array}{l}5 \\
4 \\
5\end{array}$ & $\begin{array}{l}6(0.55) \\
3(0.60) \\
3(0.27)\end{array}$ & $\begin{array}{l}0 / 3 \\
2 / 5(0.40) \\
4 / 10(0.40)\end{array}$ \\
\hline
\end{tabular}

TABLE III.-Effects of Prophylactic Graft Irradiation, Antilymphocyte Globulin, and Tissue Matching on Major Early Rejection Episodes and Late Graft Function

\begin{tabular}{|c|c|c|c|c|c|c|}
\hline \multirow{2}{*}{$\begin{array}{l}\text { No. of } \\
\text { Patients }\end{array}$} & \multirow{2}{*}{ Rads } & \multirow{2}{*}{$\begin{array}{c}\text { Anti- } \\
\text { lymphocyte } \\
\text { Globulin }\end{array}$} & \multicolumn{2}{|c|}{$\begin{array}{l}\text { Tissue } \\
\text { Match }\end{array}$} & \multirow{2}{*}{$\begin{array}{l}\text { Patients with } \\
\text { Major Early } \\
\text { Rejection } \\
\text { Episodes } \\
\text { (Fraction) }\end{array}$} & \multirow{2}{*}{$\begin{array}{l}\text { Patients with } \\
\text { Normal Serum } \\
\text { Creatinine } \\
12+\text { Months } \\
\text { (Fraction) }\end{array}$} \\
\hline & & & A-B & C-D & & \\
\hline 10 & $0-300$ & \pm & 4 & 5 & $6(0.60)$ & $2 / 9(0.22)$ \\
\hline 8 & $450-600$ & + & 2 & 5 & & $\begin{array}{l}0.2>P>0.1 \\
4 / 8(0.50)\end{array}$ \\
\hline 8 & 600 & 0 & 7 & 1 & $\begin{array}{l}P=0.026 \\
5(0.63)\end{array}$ & \\
\hline
\end{tabular}

was indeterminate). The fraction of patients experiencing significant early rejection episodes in the group receiving antilymphocyte globulin for two weeks or more was about half that in the other two groups, but the differences are not statistically significant. There are also no statistically significant differences between the three groups with regard to graft function 12 months or more after transplantation.

Prophylactic Graft Irradiation.-The effects of prophylactic graft irradiation, antilymphocyte globulin administration, and tissue matching are analysed in Table III. Twenty-six patients are suitable for analysis. Eight received $600 \mathrm{rads}$ of prophylactic graft irradiation but no antilymphocyte globulin. A further eight received 450 or 600 rads of prophylactic graft irradiation and all received antilymphocyte globulin for at least two weeks. In the final group of 10 patients graft irradiation and antilymphocyte globulin administration were erratic. None of the eight patients who received both prophylactic graft irradiation and antilymphocyte globulin for at least two weeks experienced significant early rejection episodes, compared with fractions of 0.60 and 0.63 in the other two groups. These findings are statistically significant on $\chi^{2}$ analysis using the exact method $(\mathrm{P}=0.013$ and 0.026 respectively). These differences cannot be ascribed to better histocompatibility as fewer patients in the group receiving prophylactic graft irradiation and antilymphocyte globulin had good tissue matches. Normal graft function 12 months or more after transplantation was more frequent in the group receiving prophylactic graft irradiation and antilymphocyte globulin, but this is not significant at the $5 \%$ level. None of the eight patients receiving irradiation only has been followed up for a year.

Early Rejection Episodes and Late Graft Function.-The frequency of normal graft function at intervals of 3 to 24 months after transplantation in patients who did and did not experience major early rejection episodes is shown in Fig. 1. There is no difference between the groups at six months, when $70 \%$ of all the patients had normal graft function. A difference is discernible at nine months, and between 12 and 24 months the lines diverge widely.

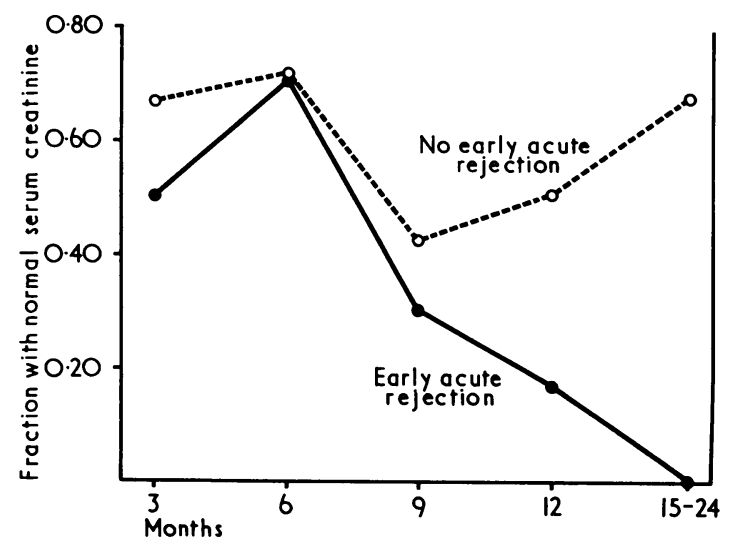

FIG. 1.-Effect of major early rejection episodes on later graft function. 


\section{Discussion}

Though the one- and two-year survival figures of kidneys from cadaver donors in the seventh report of the Human Kidney Transplant Registry (1969) are $42 \%$ and $40 \%$ respectively, better results have been reported from individual centres (Calne et al., 1969; Marshall et al., 1968; Moore and Hume, 1969). In the present series of 27 cadaver kidney recipients only one kidney has been lost from rejection 3 to 25 months after transplantation, and the only death occurred from pulmonary embolism five months after transplantation in a patient with normal graft function. The one-year patient survival in 18 patients is $94 \%$ and the one-year graft survival is $89 \%$. Moore and Hume (1969) stated that the critical period for assessing cadaver kidney transplantation is probably two years as, in their experience, there was a substantial fall-off from $70 \%$ to $48 \%$ between one and two years. In the present series all five patients transplanted 18 to 25 months ago have functioning first grafts, but mean serum creatinine levels for the entire group show a gradual rise with the passage of time (Fig. 2). This probably reflects the effect of chronic humorally mediated rejection.

It is notoriously difficult to assess the effects of individual factors in the complex setting of human kidney transplantations. In the present series a standardized basic immunosuppressive regimen has facilitated the analysis of the effects of three variable factors-tissue matching, antilymphocyte globulin administration, and prophylactic graft irradiation.

There is now very strong evidence that compatibility with respect to the HL-A system significantly influences the outcome of kidneys transplanted from related living donors, particularly in sib-sib combinations (Singal et al., 1969). Evidence for such an effect in grafts from cadaver donors has been much less convincing, but it does suggest an influence on both long-term (Patel et al., 1968; Batchelor and Joysey, 1969; van Rood, 1969) and short-term (Morris et al., 1968) graft survival. The present series fails to show a beneficial effect of good matching on either the occurrence of major early rejection episodes or graft function 12 months or more after transplantation. It must be emphasized, however, that in an

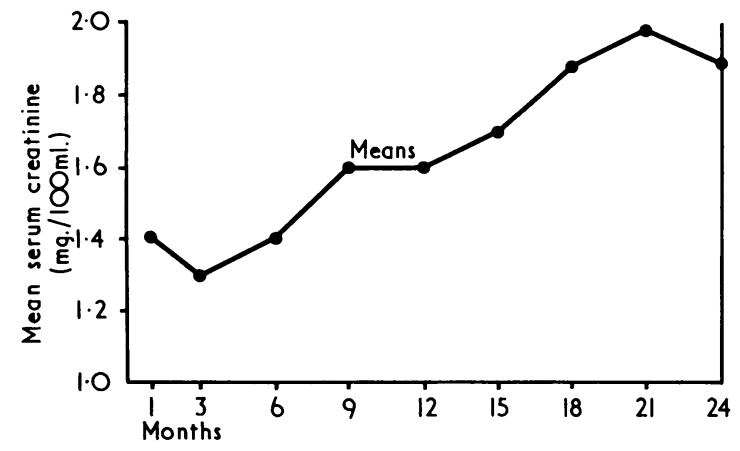

Fig. 2.-Mean serum creatinine levels 3 to 24 months after cadaveric renal transplantation. appreciable number of donors and recipients the phenotype was not saturated with respect to antigens determined by the first and second subloci of the HL-A system. It is therefore perfectly conceivable that combinations designated as $\mathbf{B}$ matches were in fact $\mathrm{C}$ or even $\mathrm{D}$ matches.

Excellent results have been reported with the use of antilymphocyte globulin in related living donor transplants (Starzl et al., 1968), but comparable results have been reported without the use of antilymphocyte globulin. There is very little evidence concerning the value of antilymphocyte globulin in cadaver kidney transplants. In the present series a prophylactic course of at least two weeks was associated with an appreciable but not a statistically significantly lower incidence of major rejection episodes. This could not be accounted for by a better distribution of good tissue matches in this group. No effect was discernible on graft function at 12 months.

The fifth report of the Human Kidney Transplant Registry (Murray et al., 1967) suggested that prophylactic graft irradiation had a beneficial effect on the course of cadaveric renal transplantation. This was not confirmed in a subsequent report (Advisory Committee of the Human Kidney Transplant Registry, 1969). Individual centres using prophylactic graft irradiation, however, have reported excellent results in cadaveric kidney transplantation (Marshall et al., 1968; Moore and Hume, 1969). In the present series patients receiving a combination of prophylactic graft irradiation and two weeks or more of antilymphocyte globulin fared better than patients receiving graft irradiation without antilymphocyte globulin or patients receiving these modalities of treatment in an erratic way. This effect was not associated with better tissue matching. It was statistically significant with respect to the occurrence of major early rejection episodes and appreciable, though not significant at the $5 \%$ level, with respect to graft function at 12 months. The beneficial effects of avoiding major early rejection episodes on late graft function was also apparent for the entire series.

Requests for reprints should be addressed to Professor J. A. Myburgh Department of Surgery, University Medical School, Johannesburg, South Africa.

\section{REFERENCES}

Advisory Committee of Human Kidney Transplant Registry (1969) Transplantation Proceedings, 1, 197.

Batchelor, J. R., and Joysey, V. C. (1969). Lancet, 1, 790

Calne, R. Y., et al. (1968). British Medical fournal, 2, 404

Marshall, V., Kincaid-Smith, P., Morris, P. J., Saker, B., and Eremin, J. (1968). Lancet, 2, 927

Moore, T. C., and Hume, D. M. (1969). Annals of Surgery, 170, 1.

Morris, P. J., Kincaid-Smith, P., Ting, A., Stocker, J. W., and Marshall, V. C. (1968). Lancet, 2, 803. Murray, J. E., Barnes, B. A., and Atkinson, J. C. (1967). Transplantation,

Myburgh, J. A., et al. (1969). New England fournal of Medicine, 281, 131

Patel, R., Mickey, M. R., and Terasaki, P. 1. (1968). New England fournal of Medicine, 279,501 .

Seventh Report of Human Kidney Transplant Registry (1969). Transplantation, 8, 721 .

Starzl, T. E., et al. (1968). Surgery, Gynecology and Obstetrics, 126, 1023.

Singal, D. P., Mickey, M. R., and Terasaki, P. I. (1969). Transplantation,

van Rood, J. J. (1969). Lancet, 1, 1142. 